\title{
REVIEW OF TAXATION REGULATORY DOCUMENTS ISSUED IN THE PERIOD OF SEPTEMBER THRU OCTOBER 2013
}

\author{
L.Anisimova
}

Although the latest period saw failure in coping with economic stagnation in Russia, it should be noted that Russian's economy demonstrated a good stress resistance. In our opinion, this can be indicative of its gradual adaptation to the market. The 'budget rule' has proved efficient - the fiscal relations system didn't collapse due to high water in the area of Amur River; Pushkino Bank's (the Moscow Oblast (Region)) sudden bankruptcy required no extra infusion of public funds and was localized with the resources allocated by the Deposit Insurance Agency. This is all indicative of that protection mechanisms of public finances were actuated in a proper manner in emergency, there was no need to increase tax burden or resort to unscheduled emergency-related fundraising. The key topic of discussion in the period under review a new pension formula and proposal to use its funded component to finance pay-as-you-go system in 2014. Furthermore, certain tax initiatives which needs to be polished were discussed in the economic process.

The pension reform decision whose principal target is mitigate the deficit in the Pension Fund of the Russian Federation (PFR) by reallocation of the funded component of a pension is intended to ensure sustainability of the budget system and undercut the inflation effect of the funded component. In our opinion, it was the only good decision that could be accepted under the current circumstances ${ }^{1}$. At the same time,

1 For reference: $\mathrm{Rb}$ 12,8 trillion federal budget revenues in 2012 (Federal Law No. 254-FZ dd. 30.09.2013) included Rb 2,8 trillion of inter-budget transfers to the PFR's budget. Total PFR's revenues ( $\mathrm{Rb}$ 5,9 trillion) included $\mathrm{Rb} 3$ trillion of social insurance contributions payable to the PFR (Federal Law No. 255-FZ dd. 30.09.2013), i.e., $22 \%$ of federal budget revenues were allocated to finance the PFR, accounting for $47.5 \%$ of total PFR's revenues. It will be recalled that the funded component (6\%) transferred to the banking system accounts for about $1 / 3$ of social insurance contributions to the PFR. The gap in funding current expenditures is additionally covered with budget transfers, thereby setting up the tax pressure. Some disagree with the pension innovations offered by the Russian Government - see, Е. Гонтмахер, «Народ, деньги есть? А если найду?», сайт МК.ru от 6.10.2013 [E. Gontmaher, "People, do you have money? What if I say you do? MK.ru dd. 6.10.2013] MK.ru/free-theme/article/2013/10/06/926187.

In our opinion, there is one thing that the ongoing discussion on pension ignores - the social insurance contributions rate which accounts for $30 \%$ of the payroll - marginal acceptable rate which ensures neutrality in allocation of a brand new product (save for profit) among the three generations for the purpose of simple reproduction: the middle age generation have to pay from their salary to maintain themselves, the younger generation, and the older generation. Should the resources accrued according to this proportion are insufficient to maintain the older generation, the increase in such resources would 'merely' result in reduction of the resources of younger generations, being similar to self destruction of the society. This is why, in spite of all the reproaches regarding non-expediency of the refusal in 2014 to transfer the funded component under individuals' control, we believe that it is only the balance between current contributions to and payments from the Fund, with a marginal limit on the social insurance contribution rate $(30 \%$ of the payroll), that can be the initial point of the pension reform. restoration of the balance between the PFR's current revenues and expenditures makes it possible to launch a discussion about whether it is reasonable or not to replace the source of insurance contributions by carrying such contributions from corporate costs over to employees' salary and emoluments and other personal incomes. This could resolve many issues and, above all, optimize the amount of such contributions, discontinue unjustified benefits for certain categories of employees, release ungrounded tax pressure upon the cost of goods (works, services), ensure predictability of investment-related costs incurred by manufacturers. Changes to the source of insurance contributions will definitely have to be explained to the effect that it would have no adverse impact upon real wages (because in nominal terms the latter will simply be raised by the amount of insurance contributions), as well as require addressing the issue of nondiscrimination of migrants and subsequent creation (under certain circumstances) of pension liabilities to migrants. Increase in both the retirement age and pensionable amount of compulsory seniority, as recommended by the IMF, could seriously mitigate the issue.

In our opinion, changes to the source of contributions payable to public social insurance extra-budgetary funds could be the most significant precondition for restoring congenial investment climate in the Russian Federation.

The PFR's share in social insurance contributions is $22 \% / 30 \%=$ $73.3 \%$. The marginal amount that can be mobilized in the PFR $=75$ million of employed $\times 30,000$ average monthly salary $\times 12$ months. $\times 30 \% \times 73.3 \%=\mathrm{Rb} 5,9$ trillion. This amount exactly corresponds to the PFR's revenues in 2012, i.e., much as they would like to retain the funded component, under the current circumstances it 'breaks through' a 30\% marginal restrictive rate on social charges, because of the need to provide additional compensation with budget funds for the uncovered current expenditures to pay pensions. 
Special attention should be focused on a few other issues that received coverage in economic publications.

A proposal to exempt from taxation capital gains with regard to government bonds ${ }^{1}$ was made once again, 17 years on after the crisis in 1998. It will be recalled that at that time tax exemption of the income generated from the GKO (Government Short-Term Commitments) bid-offer spread ${ }^{2}$ in the secondary market facilitated a higher-than-anticipated growth in the demand for these government bonds ${ }^{3}$ and eventually resulted in insolvency of the state. This is why, in our opinion, an exemption from capital gains tax with regard to bonds would be quite a hasty measure. Should the bid-offer spread be subject to tax exemption, the budget might be exposed to a specific risk, in which case profit tax allowance would be unlimited in terms of volume. Tax allowance on the income (interest/discount) predetermined (preset) during securities issue is confined to the amount of such income (interest rate/discount), IPO price or stated interest limits, and has no such devastating effect as the exemption from capital gains tax with regard to securities ${ }^{4}$.

1 «Минфин освободит от налогов доходы от государственных облигаций», сайт lenta.ru от 9.10.2013. «...Сейчас российские компании платят 15 процентов с купонного дохода и 20 процентов от прироста стоимости облигаций. В то же время иностранные инвесторы от этого налога освобождены». [“Minfin will provide tax exemption on the government bond income", lenta.ru website dd. 9.10.2013. "...Russian companies currently pay 15 percent from the coupon yield and 20 percent from capital gain on bonds. However, foreign investors are exempted from this tax". ]

2 Issued according to the Council of Ministers' Order, the Russian Government dd. 8.02.1993, No. 107.

3 See p. 4, the Letters issued by the State Tax Service of Russia (hereinafter referred to as the STC RF) No. NP-6-01/362 dd. 23.09.1994; the Ministry of Finance of Russia No. 130 dd. 21.09.1994; registered with the Ministry of Justice of Russia on November 3, 1994, No. 719 (as amended in 1995): “...имеются льготы по следующим доходам (полностью освобождаются от налогообложения): ...сумма дисконта (положительная разница между балансовой стоимостью и ценой реализации (погашения) государственных краткосрочных бескупонных облигаций), включая их реализацию на вторичном рынке..." ["...there are tax allowances on the following types of income (totally exempted from taxation): ... the discount amount (positive difference between the book value and the redemption price of the government short-term zero coupon bonds), including their realization in the secondary market..."].

4 Qualifying interest for allowance means nothing but economically unreasonable refusal of the state to receive the taxes due to the state, in particular on Eurobonds - interest recipients are not exempted from taxation at their place of fiscal residence. With regard to the bid-offer spread tax exemption, securities constitute movable property, and under double taxation conventions the movable property is subject to taxation at the place of fiscal residence of the owner (seller) of such movable propertyy. In other words, it is a simple application of double taxation conventions rather than a special privileged taxation regime established in Russia for foreign nationals, as presented by the authors of some publications.
The issue of (at least partly) reallocation of income related to personal income tax ${ }^{5}$ withheld by the employer at the employee's work place and payable to the budget at the employee's place of residence has sharpened again. A draft law introducing changes to the personal income tax payment scheme was submitted to the State Duma of the Russian Federation for consideration. Members of the Murmansk Regional Duma (the region is facing labor migration outflow) proposed that contributions be payable at the individuals' place of residence rather than the place of registration of the entity in which they are employed. Not surprisingly, the initiative encountered stubborn opposition on the side of the Ministry of Finance of Russia and a few members of the State Duma Budget Commission (in particular, Dmitrieva O. G.). Those who oppose the initiative have the same old arguments they provided before - the initiative is technically difficult, costly, and unreasonable.

As a matter of fact, the feasibility issue refers to economic issues. Obviously, there is no direct economic contradiction in paying a most secure and conflict-free tax to the budget at the individual's or his/her family's ${ }^{6}$ place of residence, quite the opposite, it is economically unreasonable not to do that. In our opinion, designing a fiscal system should be based on the prevalence of the principle of equity, and personal income tax should be at least allotted among the budget at the place of employment and residence of the individual. Such arguments as technical complexity and high cost are vicious in the era of advanced Internet. The technical complexity that will be shown below can be surmounted, and the individual will neither have to personally visit the tax office to file his/her tax return nor transfer the tax to his/her regional budget.

To technically resolve the issue, a few steps should be taken, as follows:

1) Since TIN (Taxpayer Identification Number) may be assigned only once and cancelled upon taxpayer's death, it should be complemented with two additional

5 Т. Ширманова, «Депутаты предлагают платить подоходный налог по месту жительства. Идея, которая подверглась критики министерств, опять представлена на рассмотрение Госдумы», сайт izvestia.ru от 7.10.2013 г. [Т. Shirmanova, "MPs suggest income tax be paid at the taxpayer's place of residence. The idea which faced criticism of ministries has again been submitted to the State Duma for consideration", izvestia.ru website dd. 7.10.2013. ] 6 All the more so, introduction of the real property tax was postponed for at least a year, because of the difference between abutting real property owners' income and unmatched data of the Russian State Register and the Federal Tax Service of Russia (hereinafter - the FTS RF).

See also: Д. Ивашкина, «Минфин на год отложил введение налога на недвижимость», сайт kp.ru от 18.10.2013 [D. Ivashkina, "Minfin postpones the real property tax for a year", kp.ru website, dd. 18.10.2013] 
TRRCs (Tax Registration Reason Code) for individuals - at the place of permanent residence (permanent registration, registered domicile) and for each place of employment (by the way, every individual already has more than one TRRCs - at the place of registration of immovable property and motor vehicles) ${ }^{1}$;

2) include a certificate issued by the local tax inspectorate on the submission of the TRRC application at the new place of permanent residence (registered domicile or permanent registration) into the list of documents to be submitted to the Resident Registration Office for the purpose of domicile registration (registration at the permanent place of residence);

3 ) the individual must provide the accounting office at every place of employment with a certificate bearing the TRRC number at the permanent place of residence (registered domicile or permanent registration) issued by tax authorities;

4) post information on the nalog.ru website about all TRRCs linked to the taxpayer's (physical body's) TIN.

This is for a reason that we only refer to the personal income taxpayer's place of permanent residence (registered domicile or permanent residence): if the individual hires an apartment or a room to be able to live as close as possible to his/her place of employment, he/ she pays a rent to the owner of the apartment (room), and the latter as separate taxpayer is to pay the rent income tax to the budget at the place of his/her residence. This is why, in our opinion, no confusion or difficulties whatsoever can be encountered in allocating the personal income tax charged by the employer and its partial redirection to the budget according to the TRRC at the employee's place of permanent residence.

Following are the documents that came into force in the period under review and play an important role in the regulation of taxation and are worth describing.

1. The Federal Law dd. 30.09.2013, No. 260 "On the Amendments to Part 3 of the Civil Code of the Russian Federation". This Federal Law plays a special role in determining the rules for selecting a legislation in resolving the issues concerning the commencement, execution and transfer of ownership rights, exercise the title and property right, contractual right in the course of operation of foreign legal entities on the territory of the Russian Federation, settlement of property disputes which may arise.

In particular, the Federal Law establishes that if a foreign legal entity operates predominantly on the

1 The Order of the Ministry of Finance of Russia and the FTS RF dd. 29.07.2012, No. MMV-7-6/435 "On the Establishment of the Procedure and Terms for the Assignment, Application as well as Modification of the Taxpayer Identification Number" (Registered in the Ministry of Justice of Russia on August 14, 2012, No. 25183). territory of the Russian Federation, liability under the commitments assumed by its founders (interest holders) and other persons authorized to give binding orders are subject to the Russian law or, as the creditor may choose, the personal law of such legal entity (Article 1202, Paragraph 2, Subparagraph 9 thereof).

Articles 1205-1207 specify the concept of, the property covered by, and the procedure for exercising the property right. In particular, it is established that commencement and termination of ownership rights and other rights to a property shall be determined under the law of the country where the property was located at the moment when the action or any other fact took place, giving rise to the commencement or termination of ownership rights and other property rights, unless otherwise stipulated by the law. In other worlds, foreign legal entities may not sell a real property situated on the territory of the Russian Federation under laws other then the law of the Russian Federation, because such a deed is simply declared null and void under the law of the Russian Federation.

Article 1210 establishes that imperative norms of law prevail, and in the conclusion of an agreement the parties thereto may not discretionary choose for the conclusion of the agreement and settlement of disputes the norms of law of a country whose territory is extraneous to all the facts related to the subject matter of relations between the parties thereto.

Articles 1222, 1222.1 establish the law of the state to govern liabilities arising due to unfair competition, restriction of competition, liabilities arising due to unfair conduct of negotiations on the conclusion of an agreement, etc.

2. The Federal Law dd. 30.09.2013 No. 267-FZ makes amendments to the Tax Code of the Russian Federation (hereinafter referred to as the TC RF) with regard to the specifics of taxation of regional investment projects implemented in the Far Eastern District, the Zabaikalye Territory, the Irkutsk Region, and the Buryat Republic.

The concept of 'regional investment project participant' was introduced. The taxpayer may be entitled to tax allowances if the taxpayer is recognized as a participant of such a project and the project is not designed to produce (process) crude carbohydrates, manufacture excisable goods (save for motor cars and motor bikes). Project's lifespan and payoff period depends on the volume of capital investments: six years of project's lifespan are established if capital investments of $\mathrm{Rb} 50-499 \mathrm{~m}$ are made within three years, and 10 years of project's lifespan are established if capital investments of more than $\mathrm{Rb} 500 \mathrm{~m}$ are made within five years. Taxpayers who obtain the status of investment 
projects' participants are entitled to a $0 \%$ profit tax rate with regard to the amount credited to the federal budget, and the profit tax rate credited to the budget of a constituent territory of the Russian Federation within the first half of project's lifespan may not exceed $10 \%$, and may not be less than $10 \%$ in the second half of project's lifespan. The project participant is eligible for a reduced interest rate if revenues earned from sales of goods manufactured as part of the project account for at least $90 \%$ of total booked income. A decreasing coefficient of the mineral extraction tax rate, depending on the location of a field (increasing from 0 to 1 within 24 fiscal periods on the mineral extraction tax), was introduced.

The taxpayer may obtain the status of regional investment project participant 1 ) if capital investments result in the construction of manufacturing facilities exclusively on the territory of the Far Eastern District, the Zabaikalye Territory, the Irkutsk Region, and the Buryat Republic; 2) if the taxpayer isn't integrated into consolidated groups; 3 ) if the land parcels where the project will be implemented are not owned by other legal persons and physical bodies (save for certain types of infrastructural objects); 4) if the taxpayer individually implements the project, isn't entitled to tax allowances and special regimes with regard to the activity conducted as part of the project; 5 ) if the taxpayer is registered on the territory of the Far Eastern District, the Zabaikalye Territory, the Irkutsk Region, and the Buryat Republic and has no ringfenced entities outside the foregoing territories and some other restrictions.

In addition, from January 1,2014 , if at least one of the parties to a deal participates in a regional investment project subject to a zero rate of the profit tax credited to the federal budget and/or reduced rate on the profit tax credited to the budget of a constituent territory of the Russian Federation, the deal is recognized as being regulated according to Article 105.14 of the TC RF.

3. Under the Federal Law dated 30.09.2013, No. 268-FZ, organizations engaged in the production of hydrocarbons in offshore green fields and offshore areas of green fields are subject to tax allowances. To be eligible for tax allowances, the taxpayer must be granted the status of 'offshore hydrocarbon field operator'. An organization can be recognized as such operator as long as it meets a series of requirements, namely the organization itself or its participant (founder) who also has an indirect interest in the organization must have a license for the development of a respective subsurface mineral estate; the organization is individually or with the help of subcontractors is engaged in at least one type of activity related to mineral extraction in the field; the organization and license holder has an agreement on mineral extraction on a fee basis. The license holder is entitled to enter into agreement with no more than one extraction operator at the mineral estate.

The territory of the Russian Federation is recognized as place of realization of commodities made of offshore crude hydrocarbons, as well as products of their technological conversion (stable condensate, liquefied natural gas, broad fraction of light hydrocarbons) if the commodities are located (or were located at the time of shipping) on the Russia's continental shelf and/or the exclusive economic zone of Russia or the Russia's part (Russia's sector) of the Caspian Sea floor. No provision is made for granting VAT allowance with regard to realization of hydrocarbons on the territory of the Russian Federation.

International shipping services are subject to VAT allowance. International shipping services are referred to works (services) on transportation and/or shipping of hydrocarbons from the departure point located on the continental shelf, the exclusive economic zone or Russia or the Russia's part of the Caspian Sea floor to the destination point outside the Russia's territory and other territories being under its jurisdiction. According to Article 164 of the TC RF, international shipping services are subject to a $0 \%$ VAT rate.

Paragraph 3, Article 259 thereof defines straight line depreciation as mandatory method of depreciation of fixed assets used for the production of hydrocarbons in an offshore green field of hydrocarbons (irrespective of the method provided for by the taxpayer's accounting policy).

Article 261 thereof establishes the procedure for booking natural resources development costs incurred during activities related to prospecting, appraisal and/ or exploration of offshore green hydrocarbon fields to taxpayer's expenses. Furthermore, it provides for possible deduction of costs on mineral estates which are planned to shutdown due to economic ineffectiveness, lack of geological prospects or for other reasons. Costs on the mineral estate recognized as unpromising may be 'booked' to other mineral estates in the field, provided that no more than $1 / 3$ of the such costs is booked to each mineral estate.

The voluntary insurance payable under the Russia's legislation to finance measures provided for by the oilspill response plan (Article 263 thereof) has been allowed to be charged to operating costs.

The TC RF introduces a transfer mechanism for accrued expenses on longstanding hydrocarbon production projects during license transfer. In particular, allowance is made of a build-up mechanism for provisions (Article 267.4 thereof) for future costs related to 
termination of the production of crude hydrocarbons in an offshore crude hydrocarbon green field, whose build-up starts as soon as the level of reserve depletion in the green field reaches $70 \%$. Should the mineral extraction license be transferred to a new lenience holder at this stage, the previous license holder must rebuild the accrued provisions as part of the tax base (Paragraph 7, Part 2, Article 250 thereof) and the new license holder is entitled to charge the provisions to the reduction of the profit tax base. Decommissioning costs don't include short-accrued depreciation. Therefore, taxation excludes potential overcosting at the stage of 'easy oil' production by using the abnormal depreciation mechanism and makes the production entity focus on the maximum possible development of hydrocarbon resources at the field.

Article 275.2 thereof establishes the specifics of determining the profit tax base for green fields. The taxpayer as license holder is allowed to book costs incurred at mineral estates which are recognized as inefficient to the costs on other mineral estates of the field. At the same time, the green field is regarded as stand-alone project. Neither other fields' losses, nor losses from other types of activity may decrease green field's profit (see Paragraph 4 thereof), whereas green field's losses may be charged to organization's overall performance and reduce the total tax base.

The green field's profit is subject to a $20 \%$ rate.

Articles 299.3 and 299.4 of the TC RF establish specifics of income generation and costing of taxpayers as license holders and operators. Taxpayers of the mineral extraction tax are recognized as organizations engaged in offshore hydrocarbon production. Article 338 of the TC RF establishes specifics of mineral extraction tax base formation.

Article 340.1 thereof establishes a mechanism of pricing per unit of hydrocarbons produced in the accounting period in an offshore green field on the basis of the average price in global markets and the average RUB/USD exchange rate in the accounting period. Minimum marginal price per unit of flammable natural gas or associated gas produced in an offshore green field is determined as the average weighted price - by volume of supplies to the domestic market and for export - of natural gas in the fiscal period, which is very important for equalizing the terms and conditions of gas supplies to the domestic market and for export.

Paragraph 2.1, Article 342 establishes mineral extraction tax rates applicable to the base determined in accordance with Article 338 thereof. The rates are differentiated by region in which offshore fields are located, and varying within a range of 30 to $4.5 \%$ for hydrocarbons (save for natural gas) and 1 to $1.3 \%$ for natural gas.
Transport tax allowances are granted with regard to offshore stationary and floating platforms, mobile rigs and drilling vessels, as well as property tax allowances with regard to the property located in the inland sea waters, territorial waters, continental shelf, the Russia's exclusive economic zone or in the Russia's part (Russian sector) of the Caspian Sea floor, which is used in carrying out the activity related to the development of offshore hydrocarbon fields, including geological survey, survey, mineral estate preparation works.

Exempted from customs duties are crude oil (including oil, gas and condensate produced due to technological specifics of shipment of crude oil and stable gas condensate via pipelines), gas condensate, liquefied natural gas and natural gas, broad fraction of light hydrocarbons which are produced at and moved from offshore green hydrocarbon fields, as well as the same products produced in the fields located in the southern part of the Sea of Okhotsk (brown-fields).

4. The Federal Law dd. 30.09.2013, No. 269-FZ makes amendments to the excise duties payment procedure for taxpayers.

The computation scheme for excise duties on manufacturers of alcohols and alcohol-containing products is updated. Transfer of excisable toll-manufactured products to the owner or, as instructed by the owner, to other persons if the foregoing products are sold outside the territory of the Russian Federation according to the customs export procedure, with due regard to losses (within the limits of the norms of natural loss), are exempted (Paragraph 1 Article 183 of the TC RF) from excise duties. In this case, for the purpose of being extracted from excise duty the taxpayer shall provide the tax authority with a bank guarantee not later than the $25^{\text {th }}$ date of the month of tax return submission. The bank guarantee must provide for the bank's obligation to pay in full the excise duty if the taxpayer fails to provide the documents and pay the tax. The bank guarantee must be valid within at least 10 months upon a date set for the payment of the excise duty. The validity period of the bank guarantee provided by the taxpayer for the purpose of simultaneous exemption from upfront payment of the excise duty on alcoholic and/or excisable alcohol-containing products and payment of the excise duty assessed for the foregoing products exported outside the Russian Federation according to the customs export procedure must be at least 12 months following the fiscal period in which ethyl alcohol was purchased. Not later than the date following the date of bank guarantee, the bank must notify the tax authority at the taxpayer's place of registration of the fact of bank guarantee issue. 
Excise duty rates on alcohol-containing and alcoholic products for 2016 are indexed (indexation will account for $10 \%$ of the 2015 a level). Where manufacturers of alcoholic and/or excisable alcohol-containing products buy raw ethyl alcohol in the Customs Union member-countries (hereinafter referred to as the $\mathrm{CU}$ ), the manufacturers must pay excise duty upfront (Paragraph 8 Article 194 of the TC RF) or provide a bank guarantee covering the corresponding amount. Perhaps, this measure could help somehow restrain the flow of counterfeit alcohol which flooded into Russia in response to a drastic increase in the alcohol excise duty vs. excise duties established in other $\mathrm{CU}$ membercountries.

Amendments have been made to the payment procedure for excise duties on tobacco products. Under the TC RF, at least 10 calendar days prior to the beginning of fiscal period (calendar month) the taxpayer must provide the tax authority with a notification specifying a ceiling price applicable to tobacco products. The ceiling retail price of tobacco products is referred to the ceiling (not higher) price at which the pack unit may be sold to consumers. The taxpayer shall individually set this price per retail pack unit of tobacco products separately for each trade mark (each brand name) of tobacco products (Paragraph 2, Article 187.1 of the TC RF). Since January 1, 2014 the foregoing notification must specify minimum retail prices too.

Additional adjustment was made to tax rates on the 4- and 5-grade motor gasoline, as it was provided for by the Tax Policy Guidelines for 2014-2016. The 4-grade gasoline excise duty rate will increase up to $\mathrm{Rb} 9916$ (against Rb 9416 as previously planned) in 2014, Rb 10858 (instead of Rb 10358) per ton in 2015, while the 5 -grade gasoline excise duty will increase up to $\mathrm{Rb} 6450$ (against $\mathrm{Rb} 5750$ as previously planned) in 2014, Rb 7750 (instead of Rb 6223) per ton in 2015. (Paragraph 1, Article 193 of the TC RF).

Taxpayers as holders of a no-alcohol containing products manufacturing certificate are allowed to deduct the amount of excise duty assessed during the purchase of industrial alcohol used for the production of no-alcohol containing products (Paragraph 11, Article 200 of the TC RF). To this effect, taxpayers as holders of the industrial alcohol manufacturing certificate must issue registers of invoices to buyers who manufacture no-alcohol containing products. The buyer shall provide the registers to the tax authority at the place of buyer's tax registration in order to receive the mark indicating that the buyer may deduct (credit for tax) the paid excise duty on the purchased alcohol (Paragraph 11, Article 201 thereof).

The same procedure (Paragraph 13, Article 201 thereof) for making marks by the tax authority at the buyer's premises is established with regard to registers of invoices issued by the taxpayer as supplier holding a certificate for the production of straight-run gasoline to the taxpayer-buyer holding a certificate for the refinement of straight-run gasoline (i.e., the buyer of straight-run gasoline).

5. The Federal Law dd. 30.09.2013, No. 263-FZ makes amendments to the computation procedure for mineral extraction tax and the Law of the Russian Federation "On the Customs Tariffs" (Article 3.1. thereof). The long and short of the amendments is that the export tariff declines (according to the terms of accession to the WTO) as the mineral extraction tax included into the cost increases.

The Federal Law makes changes to mineral extraction tax rates per ton of produced crude oil, gas condensate and natural gas. The mineral extraction tax rate on crude oil will amount to Rb 493 per ton in 2014, with an increase of 4.9\% against 2013 ( $R b$ 470), in 2015 the rate will increase up to $\mathrm{Rb} 530$ per ton of crude oil, and Rb 559 in 2016. Crude oil export tariffs will decline respectively: an overrun of more than $\$ 182,5$ per ton in the price of Urals crude oil in the global markets is subject to a base tariff of $\$ 29$ which is subsequently to be adjusted in 2014 by an amount equal to $59 \%$ of the overrun amount of the average price over $\$ 182,5,57 \%$ in 2015, 55\% in 2016.

Besides growth in mineral extraction tax rates on crude oil, the Federal Law is distinguished by making an attempt to introduce for owners and external users of gas transmission networks universal calculation formulas (Article 342.4 thereof) for mineral extraction tax on gas within (natural gas, gas condensate) the fields. In particular, the rate on mineral extraction tax for a field will be multiplied by the base value of the unit of fuel equivalent and the coefficient representing the degree of extraction difficulty in the field. The resulted rate should be adjusted by hydrocarbon shipping costs. And ultimate price of natural gas (gas condensate) will be determined as average weighted of the shares shipped for export and to the domestic market.

The formula is quire complex, multiple-factor, and its actual effectiveness can be evaluated in practice.

6. The Russian Government's Order dd. 26.09.2013, No. 846 approves the Rules for the establishment and application of special calculation formulas for crude oil export customs duties according to Subparagraph 2, Paragraph 5, Article 3.1. of the Federal Law "On the Customs Tariff".

The Russian Government is authorized to establish special calculation formulas for rates of export customs duties on crude oil with special physical and 
chemical characteristics produced in the oil fields located on subsoil plots which are fully or partly located within the boundaries of the Republic of Sakha Yakutia, the Irkutsk Region, the Kranoyarsk Territory, the Nenets Autonomous Area, northward of 65 degrees of latitude north of the equator fully or partly within the boundaries of the Yamalo-Nenets Autonomous District; within the Russia's part (Russian sector) of the Caspian Sea floor; within the Russia's inland sea waters floor; within the Russia's territorial waters floor; within the Russia's continental shelf.

The Order established a procedure for the submission of proposals, documents and calculations for the introduction of such special tariffs. A special formula is computed in such a way as to achieve a $16.3 \%$ internal rate of return of the field development program (Paragraph 7 thereof).

7. Given a special emphasis that has recently been placed upon the issues concerning the counteraction of the legitimization of proceeds of crime, the Ministry of Finance of Russia issued the Letter dd. October 2, 2013, No. 07-02-05/40858 which contains an extended explanation addressed to accountants and auditors. It is the first detailed analysis of the law enforcement practice which also covers explanations about measures to be taken upon discovery that an organization is engaged in financial operations with customers registered in states and territories of preferential tax treatment, organizations which fail to observe the FATF's requirements, etc.

8. The Letter of the Ministry of Finance and the FTS RF dd. September 30, 2013, No. PA-4-6/17542 as part of the implementation of the Federal Law dd. 28.06.2013, No. 134-FZ "On the Introduction of Amendments to Certain Legislative Acts of the Russian Federation With a View to Counteracting Illegal Financial Operations" contains a sensitization campaign plan and explanations with regard to further interaction between taxpayers and tax authorities.

In particular, from 1.01.2014 all VAT taxpayers (including those who are fiscal agents) will be obliged to file only electronic VAT returns via telecommunications channels through the electronic document management operator.

From January 1, 2014, electronic tax returns only may be filed through the electronic document management operator.

According to the TC RF, documents submitted to a tax authority, including invoices, must bear an enhanced encrypted and certified signature. The FTS RF noted that until the end of 2013 all electronic digital signature (EDS) certificates which taxpayers are cur- rently using must be replaced with electronic signature (ES) certified certificates. To do so, one should apply to his special purpose communications service provider.

Lists of electronic document management operators for every constituent territory of the Russian Federation are available on information stands at the territorial tax authorities and official websites of the FTS RF's Departments by constituent territory of the Russian Federation.

9. To reduce the number of tax litigations and harmonize approaches towards resolving tax issues, the Ministry of Finance of Russia and the FTS RF issued a Letter dd. October 2, 2013 No. CA-4-7/17648 which contains information about the practice of settlement of tax issues by concluding amicable agreements between taxpayers and tax authorities. Amicable agreements are subject to approval by courts of arbitration. The FTS RF instructed its subordinated authorities to take account of this court practice in their work. Furthermore, draft amicable agreements must be submitted to the Legal Department of the FTS RF for approval.

10. Russian organizations have recently been looking forward to moving their manufacturing facilities outside the Russian Federation. It is private enterprises that may move their screwdriver facilities to other countries.

In our opinion, an extreme caution should be addressed to certain public corporations ${ }^{\prime 1}$ intentions to move their screwdriver most sophisticated technology facilities to the territory of other states, alleging as the reason that foreign labor force is cheaper. Public corporations' activity in external markets is considered as moving profit-making activities of the state itself to foreign territories. We already repeatedly stated that public corporations' products may be regarded as state-subsidized, in which case subsidies will be calculated and surcharged in favor of the organizations and budgets of countries which are likely to lose their market share with the emergence of public corporations as new market players. Eventually, public corporations' products manufactured in third countries may happen to encounter lack of the demand, because they may

1 О. Самофалова, «Есть на чем сэкономить. Российские самолеты гораздо дешевле производить в Индии» [O. Samofalova, "There is something to save on. Manufacturing costs of Russian aircrafts are cheaper in India"], website vz.ru/economy/2013/10/4/653471.html от 4.10.2013. "Sukhoi Superjet-100 and MC-21 can be assembled in India. This will reduce the price by $40 \%$. It appears that India can offer a complete package of terms and conditions enhancing cost-effectiveness of manufacturing, which is not just labor costs which are lower than in Russia. According to experts, Russia will eventually benefit from it." 
lose competitive advantages as a result of forced increase in their value up to the level of independent manufacturers. Perhaps, they would have to be repurchased with Russia's federal budget resources for the reason of low liquidity. Finally, the federal budget of Russia would have to finance both construction of manufacturing facilities on a foreign territory (which may become the matter of commercial disputes on violations of free competition, like in the case with pipelines to the EU) and wages of 'cheaper' foreign labor force engaged in assembling works, instead of paying wages to Russian workers. 